\title{
Penyuluhan Pencegahan Penyakit Demam Tifoid pada Siswa-Siswi di SMAS Santa Lusia Kecamatan Percut Sei Tuan Kabupaten Deli Serdang
}

\author{
Christine Verawaty Sibuea \\ Fakultas Kedokteran Universitas HKBP Nommensen,
}

\begin{abstract}
Abstrak
Demam tifoid merupakan penyakit infeksi yang disebabkan oleh bakteri Salmonella tyhphii. Penularan demam tifoid melalui fekal oral ketika makanan atau minuman terkontaminasi bakteri Salmonella tyhphii karena kurangnya kebersihan dalam penyajian makanan atau minuman. Perilku Hidup Bersih dan Sehat (PHBS) sangat penting dalam pencegahan penularan demam tifoid ini. Penyuluhan ini bertujuan untuk memberikan edukasi tentang demam tifoid termasuk cara pencegahan penularan demam tifoid. Penyuluhan ini diberikan kepada siswa-siswa kelas XI SMAS Santa Lusia Kecamatan Percut Sei Tuan. Penyuluhan diberikan melalui presentasi, tanya jawab dan umpan balik secara daring. Umpan balik menunjukkan bahwa peserta penyuluhan dapat menerima informasi yang disampaikan dengan baik.
\end{abstract}

Kata Kunci: Tifoid, Salmonella, Penularan

\begin{abstract}
Typhoid fever is an infectious disease caused by Salmonella tyhphii bacteria. Typhoid fever is transmitted through the faecal orally when food or drink is contaminated with Salmonella tyhphii bacteria due to lack of hygiene of food or drinks. Clean and Healthy Living Behavior (PHBS) is very important to prevent the transmission of typhoid fever. This counseling aims to provide education about typhoid fever, including how to prevent the transmission of typhoid fever. This counseling was given to students of class XI Santa Lusia Senior High School, Percut Sei Tuan District. Outreach is provided through presentation, question and answer and online feedback. Feedback shows that participants can receive the information given well.
\end{abstract}

Kata Kunci: Typhoid, Salmonella, Transmission

Correspondence author: Christine Sibuea,Christine.Sibuea@yahoo.com Medan, Indonesia

\section{PENDAHULUAN}

\section{Latar Belakang Masalah}

Demam tifoid adalah penyakit infeksi akut yang biasanya mengenai saluran pencernaan dengan gejala demam lebih dari 7 hari dan gangguan pada saluran cerna. Penyakit ini lebih dikenal masyarakat dengan nama Tifus, disebabkan oleh bakteri Salmonella typhii. Demam tifoid masih merupakan masalah kesehatan yang penting di berbagai negara sedang berkembang.(1) Data World Health Organization memperkirakan angka kejadian di seluruh dunia terdapat sekitar 17 juta per tahun dengan 600.000 orang meninggal karena penyakit ini dan $70 \%$ kematiannya terjadi di 
Asia. Diperkirakan angka kejadian dari 150/100.000 per tahun di Amerika Selatan dan 900/100.000 per tahun di Asia.(2)

Di Indonesia, penyakit demam tifoid bersifat endemik. Penyakit ini tersebar di seluruh wilayah dengan jumlah yang tidak berbeda jauh antar daerah. Menurut data WHO, penderita demam tifoid di Indonesia cenderung meningkat setiap tahun dengan rata-rata 800 per 100.000 penduduk.(2) Berdasarkan Profil Kesehatan Indonesia tahun 2009 jumlah kejadian demam tifoid dan paratifoid di Rumah Sakit adalah 80.850 kasus pada penderita rawat inap dan 1.013 diantaranya meninggal dunia. Sedangkan pada tahun 2010 penderita demam tifoid dan para tifoid sejumlah 41.081 kasus pada penderita rawat inap dan jumlah pasien meninggal dunia sebanyak 276 jiwa.(3)

Penularan penyakit demam tifoid terjadi melalui makanan dan minuman yang terkontaminasi bakteri salmonella typhii, dan beresiko tinggi pada tempat-tempat umum yang menyediakan makanan dan minuman, termasuk di dalamnya lingkungan sekolah. Penyakit ini berhubungan erat dengan Perilaku Hidup Bersih dan Sehat (PHBS) di masyarakat.(4)

\section{Identifikasi dan Perumusan Masalah}

Pencegahan penularan penyakit demam tifoid dapat dilakukan melalui penerapan PHBS semua kalangan masyarakat termasuk siswa-siswi. Pengetahuan tentang penyakit demam tifoid dan PHBS yang dilakukan sedini mungkin pada usia sekolah akan mengurangi penularan penyakit demam tifoid. Siswa-siswi SMA SMAS Santa Lusia Kecamatan Percut Sei Tuan, Deli Serdang merupakan bagian dari siswasiswi yang memerlukan pengetahuan tentang PHBS untuk mengurangi penularan penyakit demam tifoid ini. Berdasarkan hal inilah, maka dianggap penting untuk melakukan penyuluhan tentang pencegahan penyakit demam tifoid pada siswa-siswi SMA SMAS Santa Lusia Kecamatan Percut Sei Tuan, Deli Serdang, sebagai bentuk kegiatan pengabdian masyarakat, bagian dari Tri Darma Perguruan Tinggi.

\section{Tujuan Pengabdian}

Kegiatan pengabdian masyarakat ini bertujuan untuk :

1. Meningkatkan pengetahuan mengenai penyebab dan akibat yang timbul akibat tidak menjaga kebersihan lingkungan yang berisiko penularan penyakit demam tifoid.

2. Menambah wawasan pengetahuan mengenai informasi bahaya demam tifoid.

3. Mengajak untuk berpartisipasi dan berperan aktif dalam penanganan pencegahan penyakit demam tifoid. 


\section{Manfaat Pengabdian}

Manfaat kegiatan pengabdian masyarakat ini :

1. Memberikan pemahaman untuk menjaga perilaku hidup sehat dan bersih agar terhindar dari penyakit demam tifoid.

2. Mampu menerapkan perilaku hidup yang bersih dan sehat serta meninggalkan perilaku buruk yang dulunya sering dilakukan.

\section{TINJAUAN PUSTAKA}

Penyakit demam tifoid adalah penyakit infeksi yang disebabkan oleh Salmonella typhii. Penyakit demam tifoid merupakan penyakit endemis di Indonesia dengan insidensi 3 : 1000 penduduk. Penyakit ini berkaitan erat dengan kesehatan lingkungan dan sanitasi yang buruk.(5)

Gejala penyakit demam tifoid terdiri atas 4 bagian utama yaitu prodromal, fase klinis, komplikasi dan penyembuhan. 7-14 hari setelah terinfeksi bakteri Salmonella tyhphii yang disebut sebagai bakterimia primer pertama merupakan masa prodromal.(1) Gejala klinis timbul pada bakterimia primer kedua dimana bakteri akan masuk ke peredaran darah dan menuju sistem retikuloendotelial (RES). Bila penyakit ini tidak ditangani dengan baik maka akan mengakibatkan perforasi usus, peritonitis dan septikemia pada minggu ke-3. Gejala klinis umum penyakit demam tifoid yang timbul adalah demam, lidah kotor, tidak enak atau nyeri pada perut, mual, mencret atau konstipasi, pembesaran limpa dan pembengkakan hati.(6)

Penularan penyakit demam tifoid terjadi melalui rute fecal-oral. Hal ini terjadi apabila seseorang mengkonsumsi air atau makanan yang terkontaminasi dengan bakteri Salmonella typhii atau tidak mencuci tangan dengan benar. Bakteri akan melewati asam lambung dan menginvasi membran mukosa sel intestinal. Hal ini akan menimbulkan respon inflamasi berupa gejala sistemik.(7) Bila timbul gejala penyakit demam tifoid dapat ditangani dengan memberikan obat penurun panas, banyak minum, mengkonsumsi makanan rendah serat dan membawa ke RS atau klinik terdekat secepatnya untuk ditangani lebih lanjut. Penularan penyakit demam tifoid dapat dilakukan dengan mencuci tangan dengan sabun dan air mengalir, mengkonsumsi air yang dimasak, menghindari minum dengan menggunakan es balok dari air yang tidak dimasak, mencuci bahan makanan dengan benar, memasak makanan hingga matang, menutup makanan dan imunisasi tifoid.(8) Mencuci tangan juga harus bersih dan mengenai semua daerah tangan dengan cuci tangan 7 langkah. Pencegahan penularan penyakit demam tifoid di sekolah dapat dilakukan dengan menerapkan Prilaku Hidup Bersih dan Sehat di sekolah (PHBS).(4) Kegiatan PHBS di sekolah dapat dilakukan 
dengan mencuci tangan dengan air bersih yang mengalir dan memakai sabun, jajan di kantin sekolah yang terjamin kebersihan dan sehat, membuang sampah pada tempatnya dan mengikuti kegiatan olahraga di sekolah. Bila PHBS ini diterapkan, lingkungan sekolah yang terdiri dari guru, siswa dan setiap orang atau petugas yang terlibat di lingkungan sekolah akan terhindar dari penyakit yang menular termasuk penyakit demam tifoid. ${ }^{(9)}$

\section{METODE PELAKSANAAN}

Bentuk pengabdian masyarakat ini berupa penyuluhan dengan presentasi, pemutaran video, tanya jawab, kuis dan umpan balik yang dilakukan secara daring menggunakan zoom.

\section{HASIL DAN PEMBAHASAN}

Kegiatan pengabdian masyarakat ini dilaksanakan dalam bentuk penyuluhan tentang pencegahan penyakit demam tifoid pada siswa-siswi SMA SMAS Santa Lusia Kecamatan Percut Sei Tuan, Deli Serdang. Dalam penyuluhan disampaikan kepada siswa-siswi tentang defenisi penyakit demam tifoid, gejala penyakit demam tifoid, penyebab menderita penyakit demam tifoid dan cara penanganan serta pencegahan penyakit demam tifoid.

Penyuluhan ini diikuti oleh 36 siswa-siswi SMA SMAS Santa Lusia Kecamatan Percut Sei Tuan, Deli Serdang dan 2 orang guru dengan distribusi peserta berdasarkan jenis kelamin laki-laki dan perempuan sama (50\%).

\section{Tabel 1. Distribusi Berdasarkan Jenis Kelamin}

\begin{tabular}{|l|c|}
\hline Jenis Kelamin & Jumlah (N/\%) \\
\hline Laki-laki & 50 \\
\hline Perempuan & 50 \\
\hline
\end{tabular}

Siswa-siswi SMA SMAS Santa Lusia Kecamatan Percut Sei Tuan, Deli Serdang terlihat sangat antusias mendengarkan penyampaian uraian dan tanya jawab tentang penyakit demam tifoid berlangsung dengan sangat baik. Hal ini dilihat dari banyaknya pertanyaan yang diajukan para peserta. Pertanyaan-pertanyaan yang diberikan peserta juga menunjukkan bahwa para peserta memperhatikan presentasi dengan sangat baik. Pertanyaan para peserta berkaitan dengan kemungkinan kontaminasi bakteri Salmonella typhii dalm air minum isi ulang, bahan makanan mentah, makanan di warung, telur mentah, es balok dan bagaimana cara pencegahan 
dari kontaminasi tersebut. Selain itu pertanyaan yang diberikan juga tentang pencegahan penularan melalui kebersihan tangan. Setalah pemaparan dan tanya jawab, diadakan kuiz bagi para peserta. Kuiz yang diadakan juga dijawab dengan sangat baik, dan hal ini menunjukkan bahwa para peserta menyimak dengan baik setiap materi yang disampaikan.

Umpan balik para peserta diperoleh dari kuesioner berupa googleform yang diisi oleh peserta. Sebagian besar peserta (69,2\%) menyatakan bahwa penyuluhan ini berlangsung sangat baik dan 23,1\% menyatakan baik. 65,4\% peserta sangat menikmati bagian penyampaian materi dan 19,2\% menyatakan sangat menikmati sesi diskusi dan tanya jawab. Sebagian besar peserta menyampaikan bahwa penyampaian materi dinilai sangat baik $(80,8 \%)$ dan 19,2\% menyatakan baik. Hampir semua peserta $(88,5 \%)$ menyatakan akan tertarik untuk mengikuti penyuluhan bila diadakan pada masa yang akan datang. Pertanyaan pada umpan balik yang berkaitan dengan penularan, pencegahan dan perilaku hidup bersih dan sehat di sekolah dapat dijawab denganbenar oleh hampir semua peserta. Umpan balik pengabdian masyarakat berupa penyuluhan pencegahan penyakit demam tifoid pada siswa-siswa SMAS Santa Lusia dapat dilihat pada tabel 2 di bawah ini.

Dari respon dan antusiasme peserta dalam tanya jawab, jawaban pada kuis dan umpan balik, dapat dilihat bahwa tujuan dari pemberian penyuluhan tentang pencegahan penyakit demam tifoid pada siswa-siswi SMA SMAS Santa Lusia Kecamatan Percut Sei Tuan, Deli Serdang tercapai.

Tabel 2. Umpan balik kegiatan penyuluhan

\begin{tabular}{|c|c|c|}
\hline \multicolumn{2}{|c|}{ Pertanyaan } & Jumlah (\%) \\
\hline \multirow{4}{*}{$\begin{array}{l}\text { Jalannya kegiatan } \\
\text { peyuluhan }\end{array}$} & Sangat baik & 69,2 \\
\hline & Baik & 23,1 \\
\hline & Cukup baik & 7,7 \\
\hline & Tidak baik & - \\
\hline \multirow{3}{*}{$\begin{array}{l}\text { Bagian Penyuluhan yang } \\
\text { paling dinikmati }\end{array}$} & Penyampaian materi & 65,4 \\
\hline & Diskusi dan tanya jawab & 26,9 \\
\hline & Peragaan jingle & 7,7 \\
\hline \multirow{3}{*}{$\begin{array}{l}\text { Ketertarikan untuk } \\
\text { mengikuti penyuluhan } \\
\text { yang akan datang }\end{array}$} & $\mathrm{Ya}$ & 88,5 \\
\hline & Tidak & - \\
\hline & Mungkin & 11,5 \\
\hline \multirow{2}{*}{$\begin{array}{l}\text { Penilaian penyampaian } \\
\text { materi }\end{array}$} & Sangat baik & 80,8 \\
\hline & Baik & 19,2 \\
\hline
\end{tabular}




\begin{tabular}{|l|l|c|}
\hline \multirow{2}{*}{$\begin{array}{l}\text { Pengetahuan penularan } \\
\text { demam tifoid }\end{array}$} & Cukup baik & - \\
\cline { 2 - 3 } & Tidak baik & - \\
\hline & Benar & 100 \\
\hline \multirow{2}{*}{$\begin{array}{l}\text { Pengetahuan pencegahan } \\
\text { demam tifoid }\end{array}$} & Salah & - \\
\hline & Benar & 96,2 \\
\hline Pengetahuan PHBS & Salah & 3,8 \\
\cline { 2 - 3 } & Benar & 84,6 \\
\cline { 2 - 3 } & Salah & 7,7 \\
\hline
\end{tabular}
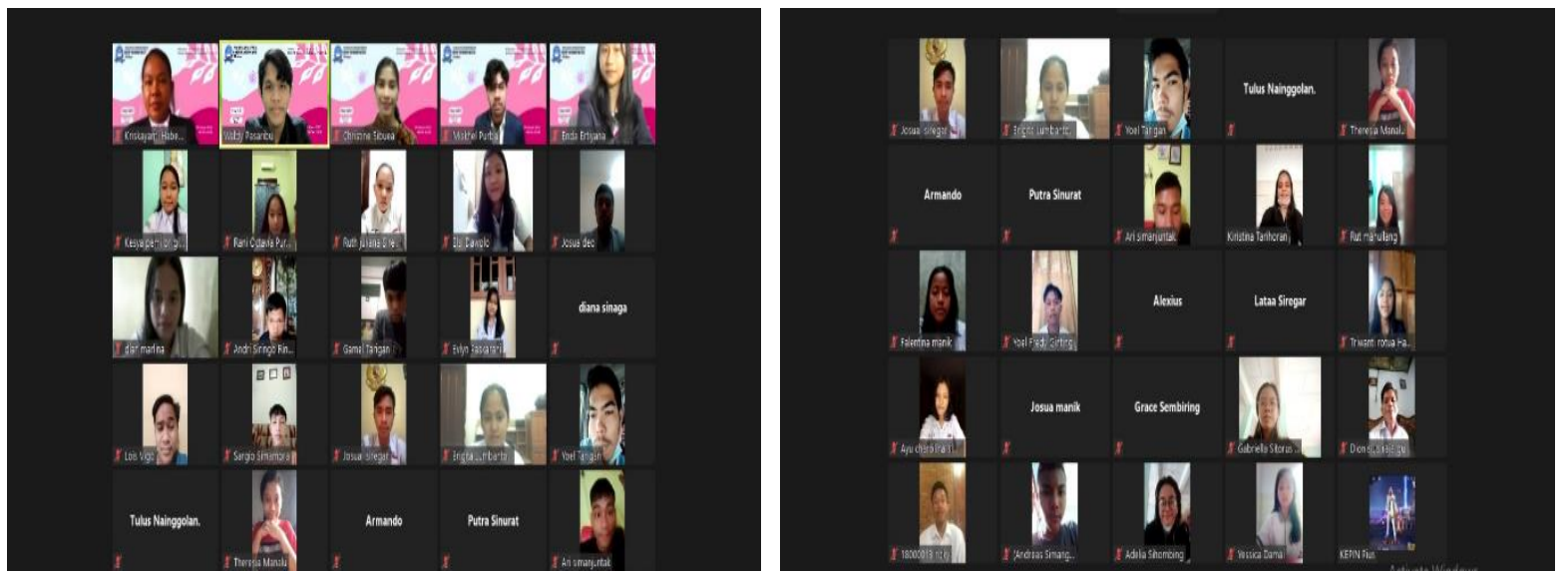

Gambar 1. Screnshoot penyuluhan pencegahan penyakit demam tifoid pada siswa-siswi SMAS Santa Lusia

\section{KESIMPULAN DAN SARAN}

\section{Kesimpulan}

Wawasan mengenai penyebab dan akibat yang timbul akibat tidak menjaga kebersihan yang berisiko terhadap penularan penyakit demam tifoid telah disampaikan dan dapat dimengerti oleh peserta penyuluhan. Ajakan untuk berpartisipasi dan berperan aktif dalam penanganan pencegahan penyakit demam tifoid juga telah disampaikan dan dapat diterima dengan baik. Tujuan dari kegiatan pengabdian masyarakat ini telah tercapai.

\section{Saran}

Pengetahuan mengenai penyebab dan akibat yang timbul akibat tidak menjaga kebersihan yang berisiko penularan penyakit lainnya dapat dilakukan melalui penyuluhan berikutnya. Ajakan untuk berpartisipasi dan berperan aktif dalam 
penanganan pencegahan penyakit menular lainnya juga dapat dilakukan melalui penyuluhan berikutnya.

\section{DAFTAR PUSTAKA}

Brusch JL. Typhoid Fever., Medscape. 2019 [dikutip 10 Mei 2021]. Tersedia pada: https://emedicine.medscape.com/article/231135-overview

World Health Organization, Typhoid 2019 [dikutip 20 April 2021]. Tersedia pada: https://www.who.int/news-room/fact-sheets/detail/typhoid

Kementrian Kesehatan Republik Indonesia. Profil Kesehatan Indonesia Tahun 2009 , Jakarta; 2010. Tersedia pada: https://pusdatin.kemkes.go.id / resources /download/pusdatin/profil-kesehatan-indonesia/profil-kesehatan-indonesia2009.pdf

Sahani W, S S, Inayah, Muspida, Askar M, Personal Hygiene Relationship with Typhoid Fever Occurrence in Gowa regency, Indonesia. Medico-legal Updat. 2020;20:14348.

Radhakrishnan A, Als D, Mintz ED, A.Crump J, Al E, Introductory Article on Global Burden and Epidemiology of Typhoid Fever. Am J Trop Med Hyg. 2018;99(3):4-9.

Bansal N. Typhoid Fever, PathologyOutlines.com. 2021 [dikutip 2 Mei 2021 ]. Tersedia pada: https://www.pathologyoutlines.com $\backslash /$ topic/colontyphoid.html Bhandari J, Thada P. Typhoid Fever. DeVos E, editor. StatPearls. StatPearls Publishing; 2020.

Medical Microbiology \& Infectious Disease Society of Pakistan. Typhoid Management Guidelines - 2019, 2021 [dikutip 20 Maret 2021]. Tersedia pada: https://www.mmidsp.com/typhoid-management-guidelines-2019/

Rusnoto, H A, ZN A, Hubungan Antara Perilaku Hidup Bersih dan Sehat (PHBS) Tentang Jajanan Tidak Sehat dengan Kejadian Thypoid pada Anak Usia Sekolah di MI NU Tamrinut Thullab Undaan Kabupaten Kudus. Univ Res Colloq. 2020;38596. 